\title{
Entrepreneurial Team: How Human and Social Capital Influence Entrepreneurial Opportunity Identification and Mobilization of External Resources
}

\author{
Ahlem Omri', Younes Boujelbene ${ }^{2}$
}

\begin{abstract}
Entrepreneurial teams play an extremely important role in the development of any country, especially in developing countries. To understand entrepreneurial teams that operate in a low-technology industry, we rely on the network and human perspective on entrepreneurship. In this paper, we investigate how the social and human capital of entrepreneurial team members influences their ability to identify entrepreneurial opportunities and mobilize external resources. We extend prior research in two ways. First, by using the ordered probit method to measure the identified entrepreneurial opportunities number at the level of entrepreneurial teams. Second, to our knowledge, there is a very small number of studies that have theoretically and empirically investigated the mobilization of external resources, especially at the level of entrepreneurial teams.
\end{abstract}

Keywords: entrepreneurial team, entrepreneurial opportunity, external resources, social capital, human capital.

\section{INTRODUCTION}

The concept of entrepreneurial team has been present since the nineties, emerging with the work of Kamm, Shuman, Seeger \& Nurick, 1990. These authors emphasized the importance of firm creation by a team, but were not interested in identifying business opportunities and mobilizing resources that are key processes for any entrepreneurial project. In our study, we have taken as reference the definition of Cohen and Bailey (1997) who considered the team as a group of individuals that share interdependent tasks and outcomes associated with these tasks, and are also seen as a social unit by themselves and by others.

1 Ahlem Omri is a Ph.D. Student in Faculty of Economics and Management of Sfax, Laboratory URECA, University of Sfax, Street of Airport, km 4.5, LP 1088, Sfax 3018, Tunisia, e-mail: omri_ahlem@yahoo.fr

2 Younes Boujelbene, Profeesor, Faculty of Economics and Management of Sfax, Laboratory URECA, University of Sfax, Street of Airport, km 4.5, LP 1088, Sfax 3018, Tunisia, e-mail: boujelbene.younes@yahoo.fr. 
Shane and Venkataraman (2000) showed that human capital increases the ability of entrepreneurs to discover and exploit business opportunities. In the same vein, Kinias (2013) confirmed that the entrepreneurial background (educational level and prior experiences) helps the entrepreneur not only in the discovery of new business opportunities, but also to recognize the tools of financing used for the future project. Prior experiences play a crucial role in the mobilization of external resources required for the opportunities identified (Kotha \& George, 2012).

Besides human capital, social capital plays a key role in the discovery of entrepreneurial opportunities as well as the mobilization of external resources by entrepreneurial teams. Packalen (2007) confirmed that social capital enhances the legitimacy of creative teams and facilitates their access to financial resources.

Although there are several studies on the entrepreneurial opportunity identification and external resource mobilization, however those interested in the processes in entrepreneurial teams are very rare. For this reason, our study aims to analyze the factors that affect the number of entrepreneurial opportunities identified by entrepreneurial team, as well as those that affect the mobilization of external resources.

\section{LITERATURE REVIEW}

\section{Human capital and entrepreneurial opportunity identification}

Opportunity identification is a step that initiates the entrepreneurial process and is the key driver for starting new businesses (Shane and Venkataraman, 2000). Then, opportunity recognition is the ancestor of both individual and social wealth, Venkataraman (1997).

The entrepreneurial team is characterized by the diversity of human capital which increases the team efficiency and therefore the performance of the company, especially during the launch and development phases of an entrepreneurial project. In addition, Eisenhardt and Schoonhoven (1990) confirmed that the unobservable human capital attributes of entrepreneurial teams are a stimulus for innovation and new ideas creation.

Some studies such as (Arenuis \& Declercq, 2005; Davidson \& Honig, 2003) showed that there is a positive relationship between education level and the ability of entrepreneurs to identify business opportunities. However, Ucbasaran, Westhead \& Wright (2009) confirmed that in a sample of 630 entrepreneurs, experienced entrepreneurs have identified and exploited more entrepreneurial opportunities than those with no prior experiences. 
Hypothesis 1: There is a positive relationship between human capital and the number of entrepreneurial opportunities identified by the entrepreneurial team.

\section{Human capital and mobilization of external resources}

First of all, Villanueva, Van de Ven \& Sapienza, (2012) indicated that resource mobilization theory is more pertinent in entrepreneurship than the theory of resources acquisition, given that the mobilization focuses on the access to resources and not on the resources allocation between the different parties.

Then, prior start-up experiences and prior industry experiences provide entrepreneurs with knowledge about the resources needed to create, and how these resources can be combined to generate more value. In addition, experience and education of the entrepreneur represent quality indices for resource holders (Hellmann \& Puri, 2002). According to Bhagavatula, Elfring, Tilburg, \& Van de Bunt, (2010) the human capital, represented by experiences and professional skills, has a direct impact on access to external financial resources. They confirmed, on a survey of 107 entrepreneurs, that those who have higher experience levels can mobilize more external resources that are useful for exploiting the opportunities identified.

Hypothesis 2: There is a positive relationship between human capital and the ability of an entrepreneurial team to mobilize external resources.

\section{Social capital and entrepreneurial opportunity identification}

The concept of social capital highlights two main dimensions that assess its added value. The structural dimension is to measure the size or the extent of social networks in terms of direct links number maintained with some categories of actors, Burt (1992). The second dimension (relational capital) refers to the nature of these links. According to Granovetter (1973), these links can be strong (strong ties) or weak (weak ties). Strong links are maintained with friends, intimate relationships or close relatives, while weak ties are related to distant parents, old friends, Lin (1995).

Moreover, (Burt, 2004; Obstfeld, 2005) have shown that individuals who have larger networks will benefit from an easier access to information, which, in turn, strengthens the possibility to benefit from opportunities and new ideas. Similarly, Singh, Hills, Lumpkin \& Hybels (1999) have shown, on a survey of 303 entrepreneurs, that the social network size has a positive influence on the ability of entrepreneurs to identify opportunities. Furthermore, weak ties are expanding the network of an entrepreneur and give him an easy access to 
new information, which helps to discover profitable business opportunities (Elfring \& Hulsink, 2003).

Hypothesis 3: There is a positive relationship between social capital of entrepreneurial teams and the number of entrepreneurial opportunities identified.

\section{Social capital and external resources mobilization}

Mobilization of external resources is often seen as a constraint for entrepreneurs. However, the entrepreneur can rely on social relationships (bankers, suppliers, clients, and friends) to mobilize funds for his company. Packalen (2007) showed that social capital enhances the legitimacy of creative teams and facilitates their access to financial resources. Moreover, (Birley, 1985; Elfring \& Hulsink, 2003) have found that the larger the social networks of entrepreneurs are, the easier access to financing is.

Besides, Uzzi (1997) confirmed that the strong relationship between the entrepreneur and the banker have positive effects on the conditions of obtaining a credit. Therefore, entrepreneurs who maintain strong links with their bankers can mobilize resources easily and at lower cost of financial resources through the high degree of confidence that characterizes such relationships.

Hypothesis 4: There is a positive relationship between social capital and the ability of an entrepreneurial team to mobilize external resources.

\section{Research model}

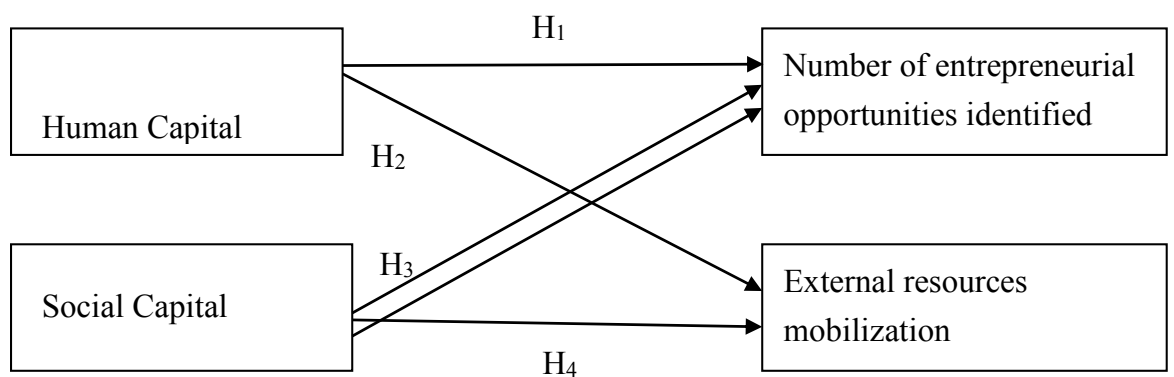

Figure 1. Conceptual model of study 


\section{METHOD}

\section{Participants}

The survey was carried out during 2013. We have adopted the technique of semi-structured interview with members of the Tunisian entrepreneurial teams in Sfax region. This region is located in the south of Tunisia and is characterized by an entrepreneurial spirit.

We tested our hypotheses with a representative sample of 225 Tunisian entrepreneurial teams from Sfax region. The target population of 225 Tunisian entrepreneurial teams was chosen according to the size (2 to 5 members) and location (Sfax region). These entrepreneurial teams belong to different sectors of the economy (shoes industry, textile industry, agribusiness, sales of automobiles). Our study is interested in the small groups, so we limited the team size to five members. In addition, we chose teams whose members have been working together since the creation of the company and aim at making their projects successful. The study was carried out by distributing questionnaires to 510 entrepreneurial teams. We received responses from only 225 entrepreneurial teams. The response rate was $44.11 \%$.

\section{Materials and procedure}

The aim of our empirical investigation is to study the relationship of human and social capital of entrepreneurial teams with identifying entrepreneurial opportunities (Burt, 2004; Davidsson \& Honig, 2003; Shane, 2003) and, secondly to study the relationship between these capitals and mobilizing external resources (Bhagavatula et al., 2010; Hulsink \& Elfring, 2003; Jenssen $\&$ Greve, 2002). To verify our research models, we used a questionnaire to collect data related to human capital and social capital of entrepreneurs, the number of entrepreneurial opportunities identified and the ease of mobilizing external resources. Next, we tested the relationship between the attributes of human capital and social capital with the number of entrepreneurial opportunities identified by the ordered probit method. However, we estimated the relationship between human capital, social capital and mobilizing external resources with a regression analysis on the Eviews software.

In this section, we use the ordered probit method to analyze the number of entrepreneurial opportunities identified. Because of the nonlinear nature of the ordered probit model, it is difficult to directly interpret the coefficients of this model, Greene (2000). Therefore, we will rely on the marginal effects analysis to better understand the impact of different variables on the entrepreneurial opportunity identification. A latent variable $y^{*}$ can model 
in a meaningful way the occurrence of an event $(\mathrm{Y})$ with reference to its probability. Greene (2000).

$$
\mathrm{Y}^{*}=\mathrm{pX} \varepsilon, \varepsilon \in[0,1](1)
$$

1 if $Y^{*} \leq \delta 1$ (the team identified one opportunity)

$Y=2$ if $\delta 1<Y^{*} \leq \delta 2$ (the team identified two opportunities)

3 if $\delta 2<Y^{*} \leq \delta 3$ (the team identified three or more opportunities)

Where $\delta 1, \delta 2$ and $\delta 3$ are boundaries that define the response categories and that are estimated at the same time with other model parameters. Marginal effects measure the impact of a "marginal" change or unit of an explanatory variable on the probability of a response choice. A marginal effect is simply the probability derivative with respect to a continuous explanatory variable $\mathrm{xj}$. Assuming that the explanatory variables are linearly in the model specification $\left.\partial\left(X^{\prime} \beta\right) / \partial x j\right)=\beta j$, we have:

$(\partial \operatorname{Prob}(Y=1)) / \partial x j=-\phi\left(X^{\prime} \beta\right) \beta j$,

$(\partial \operatorname{Prob}(Y=2)) / \partial x j=\left[\left(-\phi\left(X^{\prime} \beta\right)-\phi\left(\delta 1-X^{\prime} \beta\right)\right] \beta j\right.$

$(\partial \operatorname{Prob}(Y=3)) / \partial x j=\left[\left(-\phi\left(X^{\prime} \beta\right)-\phi\left(\delta 2-X^{\prime} \beta\right)\right] \beta j\right.$

Where $\varnothing()=.\partial \emptyset(.) / \partial\left(X^{\prime} \beta\right)$ is the density function for a normal distribution. Then, we tested the relationship between the attributes of human and social capital and the access to external resources at the level of 225 Tunisian entrepreneurial teams with a regression analysis. To use the regression technique, we verified the conditions of its utilization such as the model linearity, residuals normality and the absence of multicollinearity between the independent variables.

\section{DEPENDENT VARIABLES}

\section{Entrepreneurial opportunity identification}

Consistent with previous studies (Shepherd and Detienne, 2005; Ucbasaran et al., 2009), identification of opportunities was operationalized in terms of the number of opportunities identified. Respondents were presented with a statement asking them, "How many opportunities for creating or purchasing a business have you identified before the creation of your entrepreneurial team?". They were presented with eight opportunity identification results (that is to say, $0,1,2,3,4,5,6$ to 10 , or more than 10 opportunities). The eight opportunity identification outcomes were divided into three groups, 
and the number of respondents belonging to each group was more evenly distributed. Respondents who reported that they had identified one opportunity were allocated a score of "1", those who reported that they had identified two opportunities were allocated a score of "2" score, while those who had identified three or more opportunities were allocated a score of "3". The number of opportunities identified by an entrepreneurial team is equal to the average of opportunities identified by its members.

\section{External resources mobilization}

Access to external resources is often described as one of the main challenges faced by many entrepreneurs. Consistent with previous studies (Villanueva et al., 2012), we used entrepreneurs' perceptions of resources flows collected via questionnaire, to measure this variable. The extent to which entrepreneurial team obtained resources from the resource providers was measured in terms of the ease in obtaining different resources such as money, equipment, human resources and technical resources. Respondents were asked "to what extent is it easy to acquire money, equipment, human resources and technical resources needed to create the firm?". The answers vary according to the Likert's scale with five positions, from 1 (not easy at all) to 5 (very easy).

\section{INDEPENDENT VARIABLES}

\section{Education level}

Respondents were divided into five categories according to their education level: (1) those who had completed primary education, (2) those with a secondary education level, (3) those who had a bachelor degree, (4) those who had a license, and (5) those who had a master or doctoral degree. The answers vary based on a five-point scale from 1 (those who had primary education) to 5 (those with a master or doctoral degree).

\section{Prior managerial experience}

This variable was measured in terms of number of years of managerial experience that are reported by the respondent.

\section{Prior entrepreneurial experience}

This variable takes the value 1 if the respondent has a prior entrepreneurial experience and 0 if not. 


\section{Network size}

To measure this variable, we gave respondents a list of seven categories of links. These respondents were asked to select the links that they had personally undertaken among these seven categories. The network size of each entrepreneur is thus equal to the number of links categories that they had selected.

\section{Strong and weak ties}

To measure these two variables, we asked the respondents to indicate the nature of the relationship they had with each link they had selected. Several authors, such as (Brüderl and Preisendorfer, 1998; Lin, 1995), have reported that ties with intimate friends, spouses and close parents are considered strong, whereas those with distant parents and old friends are considered weak. The nature of relationship of each entrepreneur is equal to the number of links for each type of relationship (strong or weak) divided by the number of the link categories that he has selected.

\section{Control variables}

Age and team size were used as control variables. Age was measured as a continuous variable (between 25 and 55). The team size was measured as a continuous variable (between 2 and 5 ).

\section{RESULTS}

Means and standard deviations for the dependent, independent and control variables are reported in Table 1 . The correlation coefficients suggest that the reported regression model will not be seriously distorted by multicollinearity. We can see that the average age of respondents was 38.5 years and they had a higher or secondary education level. The average managerial experience was equal to 3.02 years while the average experience in business creation was equal to 0.62 .

For social capital, we found an average network size equal to 3.77 . The average of strong ties and weak ties are respectively about 0.55 and 0.72 . This Table confirms the average number of entrepreneurial opportunities identified to 2.42 while the access to external resources facility had an average of 3.90. Finally, the average team size was equal to 3.63. The number of entrepreneurial opportunities identified was positively correlated with weak ties and network size, however, it was negatively correlated with the team size. Mobilizing external resources was positively correlated with the entrepreneurial experiences, managerial experiences, the social network 
size and strong ties, whereas it was negatively correlated with age, team size and the education level. Thus, the number of entrepreneurial opportunities identified and mobilizing external resources were negatively correlated, which means that the greater the number of opportunities identified by the team is, the more difficult it will be to mobilize external resources.

Table 1. Descriptive Statistics and correlations of the variables

\begin{tabular}{|c|c|c|c|c|c|c|c|c|c|c|c|c|}
\hline & Mean & S.D & 1 & 2 & 3 & 4 & 5 & 6 & 7 & 8 & 9 & 10 \\
\hline 1 Age & 38.5 & 4.30 & 1.00 & & & & & & & & & \\
\hline 2 Team size & 3.63 & 1.10 & $.13^{*}$ & 1.00 & & & & & & & & \\
\hline 3 Education level & 3.2 & .84 & .009 & .04 & 1.00 & & & & & & & \\
\hline $\begin{array}{l}4 \text { Entrepreneurial } \\
\text { experience }\end{array}$ & .62 & .48 & -.08 & -.08 & -.03 & 1.00 & & & & & & \\
\hline $\begin{array}{l}5 \text { Managerial } \\
\text { experience }\end{array}$ & 3.02 & 1.16 & .004 & .05 & .04 & .023 & 1.00 & & & & & \\
\hline 6 Network size & 3.77 & .76 & -.01 & .02 & .02 & .081 & -.11 & 1.00 & & & & \\
\hline 7 Strong ties & .55 & .49 & $.15^{*}$ & -.05 & -.01 & -.003 & .002 & $.2^{* *}$ & 1.00 & & & \\
\hline 8 Weak ties & .72 & .44 & -.02 & $-.14^{*}$ & -.009 & -.022 & .10 & -.02 & .03 & 1.00 & & \\
\hline $\begin{array}{l}9 \text { Entrepreneurial } \\
\text { opportunity } \\
\text { identification }\end{array}$ & 2.42 & .67 & -.11 & $-.14^{*}$ & -.09 & .066 & .01 & $.13^{*}$ & -.05 & $.17^{* *}$ & 1.00 & \\
\hline $\begin{array}{l}10 \text { External } \\
\text { resources } \\
\text { mobilization }\end{array}$ & 3.90 & .94 & $-.15^{*}$ & $-.20^{* *}$ & $-.27^{* *}$ & $.32^{* *}$ & $.18^{* *}$ & $.24^{* *}$ & $.22^{* *}$ & .12 & -.01 & 1.00 \\
\hline
\end{tabular}

*. Correlation is significant at the 0.05 level.

**. Correlation is significant at the 0.01 level.

\section{Hypotheses 1 and 3: Entrepreneurial opportunity identification}

The results of the ordered probit analysis regarding entrepreneurial opportunity identification are presented in Table 2. Deviance as indicated by the log likelihood coefficient is a "badness-of-fit" measure, and weak "explanatory" models generally report higher deviance coefficients. The pseudo- $\mathrm{R}^{2}$ coefficient provides an indication of the "explanatory" power of the model. This Table provides information about factors that had influenced the number of entrepreneurial opportunities identified. We note that the identification of entrepreneurial opportunities was significantly and negatively influenced by the education level. Moreover, the results of the marginal effects revealed that while the education level increases by one unit, the probability of the respondents group who identified "two opportunities" increased by $2.45 \%$, while the probability of being part of those who discovered "3 or 
more opportunities" decreased by $3.36 \%$. Against the probability of being in the group who identified "one opportunity" was low.

In addition, we found that managerial experiences had significantly and negatively influenced the number of entrepreneurial opportunities identified by the Tunisian entrepreneurial teams. Therefore, the analysis of marginal effects showed that when managerial experience increases by one unit, the probability of the respondents group who identified "two opportunities" increases by $0.8 \%$. While the probability of being in the respondents group who identified "three or more opportunities" decreased by $1.08 \%$.

Entrepreneurial experiences influenced positively the entrepreneurial opportunity identification at a confidence level of $99 \%$. Moreover, an increase by one unit of these start-up experiences increases the probability of being part of the respondents group who identified "three or more opportunities" by $0.89 \%$. While the probability of being in the group that discovered "two opportunities" decreases by $0.67 \%$.

Two variables were used to measure social capital in entrepreneurial teams. These were the social network size and the weak ties. These two variables influenced significantly and positively opportunities identification at a confidence level of $99 \%$. When the network size increases by one unit, the probability of being in the respondents group who identified "two opportunities" decreases by $0.14 \%$, while the probability of being in the respondents group who identified "three or more opportunities" increases by $0.19 \%$. However, the probability of being part of entrepreneurs who discovered "one opportunity" was not significant.

Table 2. Ordered probit model

\begin{tabular}{|c|c|c|c|c|c|c|}
\hline Variables & Coefficients & SE & $P$ value & $\begin{array}{c}\text { Marginal } \\
Y=1\end{array}$ & $\begin{array}{c}\text { Effects } \\
Y=2\end{array}$ & $Y=3$ \\
\hline Age & -0.0524 & 0.0195 & 0.0074 & $-5,51931 E-07$ & 0,0045 & $-0,0065$ \\
\hline Team size & -0.1666 & 0.0842 & 0.0480 & -1,43961E-06 & 0,0047 & $-0,0063$ \\
\hline Education level & -0.4371 & 0.1127 & 0.0001 & $-2,14015 \mathrm{E}-05$ & 0,0245 & $-0,0336$ \\
\hline $\begin{array}{l}\text { Entrepreneurial } \\
\text { experience }\end{array}$ & 0.5847 & 0.1721 & 0.0007 & $-6,81601 E-06$ & $-0,0067$ & 0,0089 \\
\hline $\begin{array}{l}\text { Managerial } \\
\text { experience }\end{array}$ & -0.2485 & 0.0754 & 0.0010 & $-3,69374 \mathrm{E}-06$ & 0,0080 & $-0,0108$ \\
\hline Network size & 0.4293 & 0.1285 & 0.0008 & $-1,05208 E-06$ & $-0,0014$ & 0,0019 \\
\hline Weak ties & 0.7024 & 0.1892 & 0.0002 & $-8,53222 E-06$ & $-0,0070$ & 0,0093 \\
\hline $\begin{array}{l}\text { Akaike info } \\
\text { criterion }\end{array}$ & 1.631794 & & & & & \\
\hline Log likelihood & -174.5768 & & & & & \\
\hline (Pseudo-R2) & 0.177621 & & & & & \\
\hline
\end{tabular}


The marginal effect analysis revealed that while weak ties increase by one unit, then the probability of being part of entrepreneurs who identified "two opportunities" decreases by $0.7 \%$. Whereas the probability of being in the group who identified "three or more opportunities" increases by $0.93 \%$.

\section{Hypotheses 2 and 4: mobilization of external resources}

Table 3 contains the results of the regression analysis. This Table shows that the explanatory power of the model is acceptable (adjusted $R^{2}=0.336, p<$ 0.001 ) and the global significance allows to reject the null hypothesis which states that the coefficients are all zero $(F=17.211, p<0.001)$. The results of this model confirm that the relationship between the human capital attributes of entrepreneurial teams and the mobilization of external resources was statistically significant at a confidence level of $99 \%$.

As expected, prior entrepreneurial experiences and prior managerial experiences were positively related to the mobilization of external resources (respective coefficients: 0.52 and $0.18, p<0.001$ ). This result implies that the higher the prior entrepreneurial experience and managerial experience are, the easier the access to external resources by entrepreneurial team is. While the education level was negatively related to the dependent variable external resources mobilization. These results confirm our hypothesis 2 related to human capital (with the exception of education level).

Table 3. Regression Model of external resources mobilization variables

\begin{tabular}{lcccc}
\hline & \multicolumn{2}{c}{ External resources mobilization } & \\
& Coefficients & S E & t-Statistic & Probability \\
\hline Age & -0.0295 & 0.0122 & -2.4070 & 0.0169 \\
Team size & -0.1369 & 0.0475 & -2.8813 & 0.0044 \\
Education level & -0.3030 & 0.0610 & -4.9668 & 0.0000 \\
Entrepreneurial experience & 0.5273 & 0.1070 & 4.9276 & 0.0000 \\
Managerial experience & 0.1814 & 0.0446 & 4.0617 & 0.0001 \\
Network size & 0.2706 & 0.0693 & 3.9003 & 0.0001 \\
Strong ties & 0.3619 & 0.1070 & 3.3792 & 0.0009 \\
\hline R $^{2}$ & 0.3569 & & Durbin- & 1.4624 \\
Adjusted R & & & Watson & 225 \\
F & 0.3362 & & & \\
Prob(F-statistic) & 17.211 & & & \\
\hline
\end{tabular}

The social capital of entrepreneurial teams represented by the social network size and strong ties has significantly influenced the external resources 
mobilization at a confidence level of $99 \%$. As expected, the social network size and strong links have positively influenced the access to external resources (respective coefficients: 0.27 and $0.36, p<0.001$ ). This implies that the higher the number of strong ties and the larger the network size are, the easier the access to external resources is. These results confirm our hypothesis 4 .

\section{DISCUSSION}

Our empirical study examined the influence of human and social capital related variables of entrepreneurial teams on opportunity identification and external resources mobilization.

\section{Entrepreneurial opportunity identification}

The results of ordered probit model show that variables which represent the human capital of entrepreneurial teams have significantly influenced the identification of opportunities. Shane and Venkataraman (2000) showed that entrepreneurs with higher levels of human capital are more likely to discover perceived opportunities as sufficiently attractive to start their own business.

Prior entrepreneurial experience has positively influenced the number of entrepreneurial opportunities identified. In the same vein, Ucbasaran et al. (2009) have confirmed, based on a sample of 630 entrepreneurs, that experienced entrepreneurs identified and exploited more opportunities than novice entrepreneurs. However, the study of (Bhagavatula et al., 2010) confirmed that managerial experiences negatively affected the identification of entrepreneurial opportunities, which proves our result for prior managerial experiences. Davidsson and Honig (2003) explained this result by the fact that managerial activities may foster routines that do not facilitate the opportunity recognition and the allocation procedures that are not adapted to the successful entrepreneurial exploitation.

The third variable of human capital that has a negative influence on the entrepreneurial opportunity identification is the education level. Two possible explanations for this result: the discovery of entrepreneurial opportunities may require a specific level of education or a specific quality of training, for example entrepreneurship training. Moreover, Davidsson and Honig (2003) have shown that these human capital attributes may affect, in different ways, the opportunity identification process.

Generally, the results of our study showed that the human capital represented by the education level, prior managerial experiences and prior entrepreneurial experiences, played a key role in identifying entrepreneurial opportunities. 
The entrepreneurship literature considers social networks a key factor in the business success. Our results confirmed the role of the network size, which positively influenced the number of entrepreneurial opportunities identified by the entrepreneurial teams. Furthermore, the team members with larger networks will benefit from a greater access to information which allows them to benefit from new ideas and opportunities (Burt, 2004; Obstfeld, 2005). Similarly, Ardichvili, Cardozo \& Ray (2003) showed that the success of identifying opportunities is associated with the existence and the use of an extended social network.

In addition, our results concerning the nature of social networks showed a positive impact of weak ties on the ability of entrepreneurs to identify opportunities. According to Granovetter (1983), weak ties can be considered bridges to the new differentiated information, that gives entrepreneurs a better chance to recognize opportunities (Hill, Lumpkin \& Singh, 1997). Also, Arenius and DeClercq (2005) showed that, entrepreneurs who maintain weak ties have identified a higher number of entrepreneurial opportunities than those who have strong ties.

Thus, our study shows the importance of social capital in identifying entrepreneurial opportunities by entrepreneurial teams. The larger the social network of entrepreneurial teams and the higher the number of weak ties are, the greater the number of entrepreneurial opportunities identified is.

\section{External resources mobilization}

The human capital attributes of entrepreneurial teams have significantly influenced the mobilization of external resources. Prior entrepreneurial experiences and prior managerial experiences of the team members allow them an easy access to external resources. Beckman, Burton \& O'Reilly, (2007) showed that the probability of obtaining financial capital increases with prior managerial experiences acquired by the founding team or the management team. In addition, individuals with prior start-up experiences are likely to be aware of the resources needed to create a successful venture. These experiences also enable entrepreneurs to have more information and knowledge to choose the resource holders (Kotha and George, 2012).

Therefore, individuals with prior entrepreneurial experiences can require a high quality level for their subsequent business (Gimeno, Folta, Cooper \& Woo, 1997), the value of these companies will be, on average, higher than businesses founded by persons who have no prior entrepreneurial experiences (Kotha \& George, 2012). While Beckman et al. (2007) showed that the chances of acquiring financial resources decrease for founding teams or management teams who have prior entrepreneurial experiences. 
The last variable of human capital is the education level that has negatively influenced the access to external resources. Audretsch and Lehman (2004) showed that, in a sample of 341 German companies, the number of management team members who have a doctoral degree has no impact on access to financial capital. This result may partly explain our results with entrepreneurial team members who had a secondary or higher education level. However, Engel and Keilbach (2007) confirmed that the education level of founders crucially influenced the chance to receive financial resources from resource holders.

Thus, our results showed that the social capital of entrepreneurial teams represented by the networks size and strong ties plays a key role in mobilizing external resources. The higher the number of social relationship is, the more the entrepreneur will be able to have relations with bankers, credit institutions and resources holders. These links enable entrepreneurial teams to easily access external resources and at lower costs. In the same way, the studies of (Birley, 1985; Hulsink \& Elfring, 2003) showed that the larger the networks of entrepreneurs is, the easier the financial resources acquisition is.

Furthermore, the results of our study showed a positive influence of strong ties on external resources mobilization. Therefore, this result reflects the importance of family relationships and friendships in the creation and support of new businesses ((Ruef, Aldrich \& Carter, 2003). Similarly, Kotha and George (2012) found that family ties raise the count of personal resources that the entrepreneur can obtain. Furthermore, Bhagavatula et al. (2010) confirmed, on a sample of 107 entrepreneurs in the handloom sector, that strong ties play a crucial role in the resources acquisition process which is a key entrepreneurial process affecting the company performance.

While our study extends the entrepreneurial literature by the results found that support the importance of human and social capital to identify opportunities and to mobilize external resources, however, these results can be generalized to all Tunisian entrepreneurial teams given that our survey was carried out in the Sfax region.

Although several studies have analyzed the factors related to the mobilization of resources, a small number of researches have focused on opportunity identification by entrepreneurial teams. Our results confirm the value of prior entrepreneurial experiences and weak ties to identify a high number of opportunities. In addition, access to different resources was facilitated by informal links as well as specific human capital. These results have implications for financiers. In fact, many resource holders require prior experiences as a feature of entrepreneurs who can receive a credit bank. Future research may focus on the nature of opportunities identified by entrepreneurial teams and the ways to exploit these opportunities. 


\section{CONCLUSION}

Identification of entrepreneurial opportunities and mobilizing external resources are two key processes for any entrepreneurial project. The review of the literature on entrepreneurial teams revealed the lack of research carried out on this type of company. The purpose of this study was to empirically examine the relationship between various dimensions of human and social capital of Tunisian entrepreneurial teams and their ability to identify entrepreneurial opportunities and access to external resources.

This study has some limitations. Since this study observed one ethnic group, these findings can be specific to their contexts. The results might differ in other entrepreneurial teams from developed countries. In fact, human capital attributes and dimensions of social capital can be different across countries. Finally, in our study we restricted the analysis to internal factors of entrepreneurial team affecting the identification of entrepreneurial opportunities and the mobilization of external resources. However, there are other external factors to the entrepreneurial team such as the economic and political environment that may encourage or impede the detection and exploitation of entrepreneurial opportunities as well as obtain external resources.

Furthermore, apart from the empirical value contribution of entrepreneurial experiences in identifying entrepreneurial opportunities and mobilizing external resources, this study provides some theoretical contributions. First, we suggest that the specific human capital of entrepreneurial team members allows them to overcome the problems of resource evaluation. Second, our study shows the role of strong ties of entrepreneurs in the resources mobilization for the exploitation of entrepreneurial opportunities. Therefore, the problem of the necessary resources mobilization can be mitigating through prior experiences and informal social relations.

Future research on entrepreneurial teams can continue with our ideas to highlight the importance of human capital and social capital throughout the various phases of the entrepreneurial process, for example, to study the impact of human and social capital on the growth and success of entrepreneurial teams.

\section{References}

Ardichvili, A., Cardozo, R., Ray, S. (2003). A theory of entrepreneurial opportunity identification and development. Journal of Business Venturing, 18, 105-123.

Arenius, P., Clercq, D. D. (2005). A network-based approach to opportunity identification. Small Business Economics, 24, 249-265. 
Audretsch, D., Lehmann, E. (2004). Financing high-tech growth: the role of banks and venture capitalists. Schmalenbach Business Review, 56, 340357.

Beckman, C. M., Burton, M. D., O'Reilly, C. (2007). Early teams: the impact of team demography on $\mathrm{VC}$ financing and going public. Journal of Business Venturing, 22, 147-173.

Bhagavatula, S., Elfring, T., Tilburg, A., Van de Bunt, G. G. (2010). How social and human capital influence opportunity recognition and resource mobilization in India's handloom industry. Journal of Business Venturing, $25,245-260$.

Birley, S. (1985). The role of networks in the entrepreneurial process. Journal of Business Venturing, 1, 107-117.

Brüderl, J., Preisendörfer, P. (1998). Network support and the success of newly founded businesses. Small Business Economics, 10(3), 213-225.

Burt, R. (1992). Structural Holes: The Social Structure of Competition. Cambridge, MA: Harvard University Press.

Burt, R. (2004). Structural holes and good ideas. American Journal of Sociology, 110, 394-399.

Cohen, S. G., Bailey, D. E. (1997). What makes teams work: Group effectiveness from the shop floor to the executive suite. Journal of Management, 23(3), 9-290.

Davidson, P., Honig, B. (2003). The role of social and human capital among nascent entrepreneurs. Journal of Business Venturing, 18, 310-331.

Eisenhardt, K. M., Schoonhoven, C. B. (1990). Organisational growth: Linking founding team, strategy, environment, and growth among U.S. semiconductor ventures, 1978-1988. Administrative Science Quarterly, 35, 504-529.

Elfring, T., Hulsink, W. (2003). Networks in entrepreneurship the case of hightechnology firms. Small Business Economics, 21, 409-422.

Engel, D., Keilbach, M. (2007). Firm level implication of early stage venture capital investment: An empirical investigation. Journal of Empirical Finance, 14, 150-167.

Gimeno, J., Folta, T. B., Cooper, A. C., Woo, C. Y. (1997). Survival of the fittest? Entrepreneurial human capital and the persistence of underperforming firms. Administrative Science Quarterly, 42(4), 750-783.

Granovetter, M. (1973). The strength of weak ties. American Journal of Sociology, 78, 1360-1380.

Granovetter, M. (1983). The strength of weak ties: a network theory revisited. Sociological Theory, 1, 201-233.

Greene, W. H. (2000). Econometric analysis, $4^{\text {th }}$ edition. Upper Saddle River, NJ: Prentice-Hall.

Hellmann, T., Puri, M. (2002). Venture capital and the professionalization of start-up firms: empirical evidence. Journal of Finance, 57, 169-197.

Hill, G. E., Lumpkin, G. T., Singh, R. P. (1997). Opportunity Recognition: Perceptions and Behaviors of Entrepreneurs. In: P.D. Reynolds et al. 
(Eds.), Frontiers in Entrepreneurship Research (pp. 168-182). Wellesley, MA: Babson College.

Kinias, I. G. (2013). The importance of the entrepreneurial background in the detection and the utilization of the information. Social and Behavioral Sciences, 73, 564-572.

Jenssen, J. I., Greve, A. (2002). Does the degree of redundancy in social networks influence the success of business start-ups? International Journal of Entrepreneurial Behavior and Research, 8(5), 254-267.

Kamm, J. B., Shuman, J. C., Seeger, J. A., Nurick, A. J. (1990). Entrepreneurial teams in new venture creation: a research agenda. Entrepreneurship: Theory \& Practice, 14(4), 7-17.

Kotha, R., George, G. (2012). Friends, family, or fools: Entrepreneur experience and its implications for equity distribution and resource mobilization. Journal of Business Venturing, 27, 525-543.

Lin, N. (1995). Les ressources sociales: une théorie du capital. Revue Française de Sociologie, 36, 685-704.

Obstfeld, D. (2005). Social networks, the tertius iungens orientation, and involvement in innovation. Administrative Science Quarterly, 50(1), 100130.

Packalen, K. A. (2007). Complementing capital: The role of status, demographic features, and social capital in founding teams' abilities to obtain resources. Entrepreneurship Theory and Practice, 31(6), 873-891.

Ruef, M., Aldrich, H., Carter, N. (2003). The structure of founding teams: homophily, strong ties, and isolation among us entrepreneur. American Sociological Review, 68, 195-222.

Shane, S., Venkataraman, S. (2000). The promise of entrepreneurship as a field of research. Academy of Management Review, 25, 217-226.

Shane, S. (2003). A general theory of entrepreneurship: The individualopportunity nexus. Cheltenham: Edward Elgar.

Shepherd, D. A., DeTienne, D. R. (2005). Prior knowledge, potential financial reward, and opportunity identification. Entrepreneurship Theory and Practice, 29, 91-112.

Singh R. P., Hills, G. E., Lumpkin, G. T., Hybels, R. C. (1999). The entrepreneurial opportunity recognition process: examining the role of self-perceived alertness and social networks. Paper Presented at the Academy of Management Meeting, Chicago, IL.

Ucbasaran, D., Westhead, P., Wright, M. (2009). The extent and nature of opportunity identification by experienced entrepreneurs. Journal of Business Venturing, 24, 30-115.

Uzzi, B. (1997). Social structure and competition in interfirm networks: The paradox of embeddedness. Administrative Science Quarterly, 42, 35-67.

Venkataraman, S. (1997). The distinctive domain of entrepreneurship research: an editor's perspective. In: J. Katz, R. Brouckhaus (Eds.), Advances in entrepreneurship, firm emergence and growth. Greenwich, CT: JAI Press. 
Villanueva, J., Van de Ven, A. H., Sapienza, H. J. (2012). Resource mobilization in entrepreneurial firms. Journal of Business Venturing, 27, 19-30.

\title{
Biographical notes
}

Ahlem Omri is a PhD student at the Faculty of Economics and Management of Sfax, Tunisia. She acquired her Master's degree at the Higher Institute of Business Administration. She investigates entrepreneurial team subjects: firm creation by team, entrepreneurial team dynamics and its success.

Younes Boujelbene is a Professor of Higher Education at the Faculty of Economics and Management of Sfax. He is interested in economics, financial subjects and the field of entrepreneurship.

\begin{abstract}
Abstrakt (in Polish)
Zespoły podejmujq̨e działania przedsiębiorcze odgrywajq niezwykle ważnq rolę w rozwoju każdego kraju, a zwłaszcza w krajach rozwijajqcych się. Aby zrozumieć te zespoły, które działaja w tradycyjnych przemysłach, opartych na mniej zaawansowanych technologiach, przeprowadzono badania dotyczqce wpływu perspektyw sieciowej i zwiqzanej z zasobami ludzkimi na przedsiębiorczość. W artykule badamy w jaki sposób kapitał społeczny i ludzki członków tych zespołów wpływa na ich zdolność rozpoznawania szans przedsiębiorczych oraz mobilizacji zewnętrznych zasobów. Artykuł poszerza wcześniejsze badania na dwa sposoby. Po pierwsze, wykorzystuje metodę probit do pomiaru liczby zidentyfikowanych szans biznesowych na poziomie zespotów przedsiębiorczych. Po drugie, zgodnie z naszq wiedzq, jest bardzo niewiele opracowań, które teoretycznie i empirycznie analizowały zagadnienie mobilizacji zasobów zewnętrznych, zwłaszcza w odniesieniu do działalności zespołów przedsiębiorczych.

Słowa kluczowe: zespół przedsiębiorczy, szanse przedsiębiorcze, zasoby zewnętrzne, kapitał społeczny, kapitał ludzki.
\end{abstract}

